\title{
Sources of upper tropospheric HOx over the South Pacific Convergence Zone: A case study
}

\section{Citation}

Mari, Céline, Carine Saüt, Daniel J. Jacob, François Ravetta, Bruce Anderson, Melody A. Avery, Donald R. Blake, et al. 2002. "Sources of Upper Tropospheric HOx over the South Pacific Convergence Zone: A Case Study." Journal of Geophysical Research 108 (D2) (November 12). doi:10.1029/2000jd000304.

\section{Published Version}

doi:10.1029/2000JD000304

\section{Permanent link}

http://nrs.harvard.edu/urn-3:HUL.InstRepos:14121855

\section{Terms of Use}

This article was downloaded from Harvard University's DASH repository, and is made available under the terms and conditions applicable to Other Posted Material, as set forth at http:// nrs.harvard.edu/urn-3:HUL.InstRepos:dash.current.terms-of-use\#LAA

\section{Share Your Story}

The Harvard community has made this article openly available.

Please share how this access benefits you. Submit a story.

\section{Accessibility}




\section{Sources of upper tropospheric $\mathrm{HO}_{x}$ over the South Pacific Convergence Zone: A case study}

Céline Mari, ${ }^{1}$ Carine Saüt, ${ }^{1}$ Daniel J. Jacob, ${ }^{2}$ François Ravetta, ${ }^{2,3}$ Bruce Anderson, ${ }^{4}$ Melody A. Avery, ${ }^{5}$ Donald R. Blake, ${ }^{6}$ William H. Brune, ${ }^{7}$ Ian Faloona, ${ }^{8}$ G. L. Gregory, ${ }^{4}$ Brian G. Heikes, ${ }^{9}$ Glen W. Sachse, ${ }^{4}$ Scott T. Sandholm, ${ }^{10}$ Hanwant B. Singh, ${ }^{11}$ Robert W. Talbot, ${ }^{12}$ David Tan, ${ }^{10}$ and Stephanie Vay ${ }^{4}$

Received 27 December 2000; revised 2 July 2001; accepted 5 July 2001; published 12 November 2002.

[1] A zero-dimensional (0-D) model has been applied to study the sources of hydrogen oxide radicals $\left(\mathrm{HO}_{x}=\mathrm{HO}_{2}+\mathrm{OH}\right)$ in the tropical upper troposphere during the Pacific Exploratory Mission in the tropics (PEM-Tropics B) aircraft mission over the South Pacific in March-April 1999. Observations made across the Southern Pacific Convergence Zone (SPCZ) and the southern branch of the Intertropical Convergence Zone (ITCZ) provided the opportunity to contrast the relative contributions of different sources of $\mathrm{HO}_{x}$, in a nitrogen oxide radical $\left(\mathrm{NO}_{x}\right)$-limited regime, in relatively pristine tropical air. The primary sources of $\mathrm{HO}_{x}$ vary significantly along the flight track, in correlation with the supply of water vapor. The latitudinal variation of $\mathrm{HO}_{x}$ sources is found to be controlled also by the levels of $\mathrm{NO}_{x}$ and primary $\mathrm{HO}_{x}$ production rates $P\left(\mathrm{HO}_{x}\right)$. Budget calculations in the $8-$ to $12-\mathrm{km}$ altitude range show that the reaction $\mathrm{O}\left({ }^{1} \mathrm{D}\right)+\mathrm{H}_{2} \mathrm{O}$ is a major $\mathrm{HO}_{x}$ source in the cloud region traversed by the aircraft, including SPCZ and the southern branch of the ITCZ. Production from acetone becomes significant in drier region south of $20^{\circ} \mathrm{S}$ and can become dominant where water vapor mixing ratios lie under 200 ppmv. Over the SPCZ region, in the cloud outflow, $\mathrm{CH}_{3} \mathrm{OOH}$ transported by convection accounts for $22 \%$ to $64 \%$ of the total primary source. Oxidation of methane amplifies the primary $\mathrm{HO}_{x}$ source by $1-1.8$ in the dry regions. INDEX TERMS: 0320 Atmospheric Composition and Structure: Cloud physics and chemistry; 0365 Atmospheric Composition and Structure: Troposphere-composition and chemistry; 0368 Atmospheric Composition and Structure: Troposphere-constituent transport and chemistry; 3314 Meteorology and Atmospheric Dynamics: Convective processes; KEYWORDS: $\mathrm{HO}_{x}$, convection, SPCZ, upper troposphere, PEM-TROPICS

Citation: Mari, C., et al., Sources of upper tropospheric $\mathrm{HO}_{x}$ over the South Pacific Convergence Zone: A case study, J. Geophys. Res., 107, 8229, doi:10.1029/2000JD000304, 2002. [printed 108(D2), 2003]

\footnotetext{
${ }^{1}$ Laboratoire d'Aérologie, UMR CNRS/Université Paul Sabatier, Toulouse, France.

${ }^{2}$ Division of Engineering and Applied Science, Harvard University, Cambridge, Massachusetts, USA.

${ }^{3}$ Service d'Aéronomie, Paris, France.

${ }^{4}$ NASA Langley Research Center, Hampton, Virginia, USA.

${ }^{5}$ Department of Physics, Hampton University, Hampton, Virginia, USA. USA.

${ }^{6}$ Department of Chemistry, University of California, Irvine, California,

${ }^{7}$ Department of Meteorology, Pennsylvania State University, University Park, Pennsylvania, USA.

${ }^{8}$ National Center for Atmospheric Research, Boulder, Colorado, USA.

${ }^{9}$ Center for Atmospheric Chemistry Studies, University of Rhode Island, Narragansett, Rhode Island, USA.

${ }^{10}$ Earth and Atmospheric Sciences, Georgia Institute of Technology, Atlanta, Georgia, USA.

${ }^{11}$ NASA Ames Research Center, Moffett Field, California, USA.

${ }^{12} \mathrm{CSRC} / \mathrm{EOS}$, University of New Hampshire, Durham, New Hampshire, USA.
}

Copyright 2002 by the American Geophysical Union. 0148-0227/02/2000JD000304

\section{Introduction}

[2] Tropical regions play an important role in determining the global oxidizing power of the atmosphere because of the high UV radiation and humidity, promoting the formation of hydrogen oxide radicals radicals $\left(\mathrm{HO}_{x}=\mathrm{OH}+\right.$ peroxy radicals). Surprising results have emerged from the first measurements of $\mathrm{HO}_{x}$ radicals in the upper troposphere: observed $\mathrm{HO}_{x}$ levels were frequently 2-4 times higher than expected based on the commonly assumed primary source:

$$
\begin{gathered}
\mathrm{O}_{3}+\mathrm{h} \nu \rightarrow \mathrm{O}\left({ }^{1} \mathrm{D}\right)+\mathrm{O}_{2} \\
\mathrm{O}\left({ }^{1} \mathrm{D}\right)+\mathrm{H}_{2} \mathrm{O} \rightarrow \mathrm{OH}+\mathrm{OH}
\end{gathered}
$$

To explain the elevated levels of $\mathrm{HO}_{x}$ in the upper troposphere, new sources have been suggested. Acetone $\left(\mathrm{CH}_{3} \mathrm{C}(\mathrm{O}) \mathrm{CH}_{3}\right)$ was found to be a major source at low levels of water vapor in the upper troposphere [Singh et al., 1995; Arnold et al., 1997; McKeen et al., 1997; Wennberg et 


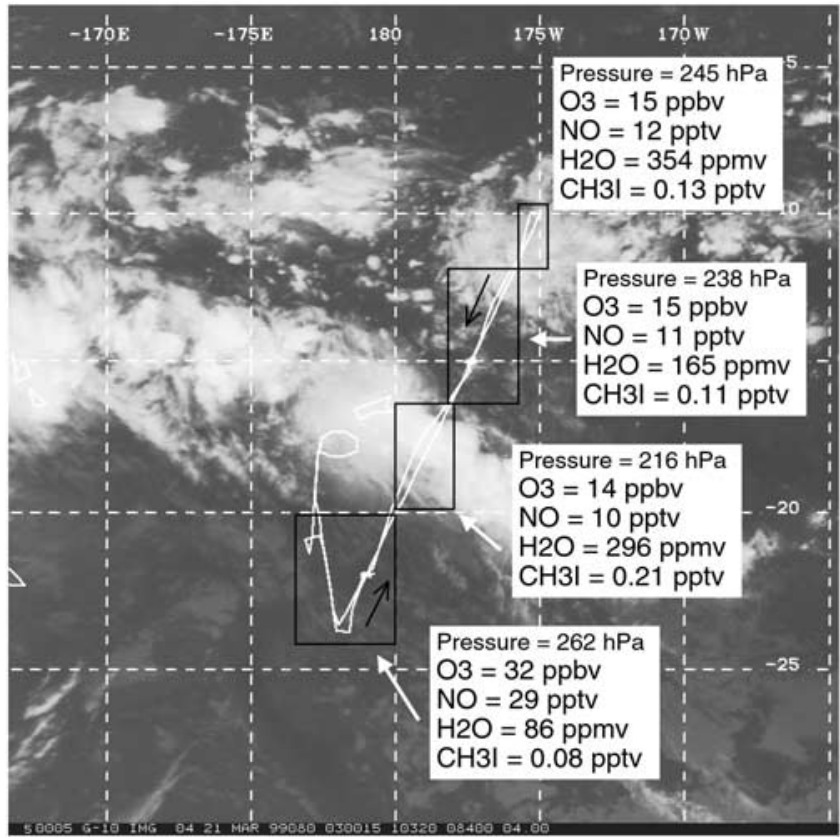

Figure 1. GEOS-10 IR satellite image for $21 \mathrm{March}$, at 0300 UTC with track of flight 10, during PEM-Tropics B experiment. Flight 10 started on 20 March, 2230 UTC, from Fiji, returning on 21 March, 0615 UTC. Median values of observed pressure (in $\mathrm{hPa}$ ), ozone (in ppbv), $\mathrm{CH}_{3} \mathrm{I}$ (in pptv), $\mathrm{NO}_{x}$ (in pptv) and water vapor mixing ratios (ppmv) are listed for four latitudinal regions: south of SPCZ $\left(24^{\circ}-\right.$ $\left.20^{\circ} \mathrm{S}\right)$, SPCZ $\left(20^{\circ}-17^{\circ} \mathrm{S}\right)$, North of SPCZ $\left(17^{\circ}-13^{\circ} \mathrm{S}\right)$ and ITCZ $\left(13^{\circ}-10^{\circ} \mathrm{S}\right)$.

al., 1998]. Recent studies have suggested that deep convection may be an effective process in lifting $\mathrm{HO}_{x}$ precursors from the boundary layer to the middle and upper troposphere [Prather and Jacob, 1997]. Several of these precursors have been identified including methylhydroperoxide $\left(\mathrm{CH}_{3} \mathrm{OOH}\right)$ [Jaeglé et al., 1997; Folkins et al., 1998; Cohan et al., 1999], formaldehyde $\left(\mathrm{CH}_{2} \mathrm{O}\right)$ and other aldehydes [Müller and Brasseur, 1999]. Photolysis of convected peroxides and formaldehyde, together with acetone seemed to provide a strong enough source to account for the observed levels of $\mathrm{HO}_{x}$. The importance of these new sources was tested successfully for northern midlatitudes [Jaeglé et al., 2001] and tropical northern and southern Pacific oceans [Crawford et al., 1999], in air masses impacted by natural (biomass burning) and anthropogenic pollution. In this paper we examine the question of the origin of $\mathrm{HO}_{x}$ radicals and the mechanism controlling the fast photochemistry of upper tropospheric $\mathrm{HO}_{x}$ in the clean tropical southern Pacific ocean during a season when biomass burning and advection of continental emitted species were low.

[3] In particular, we focus the study on the convection outflow and surrounding air from the South Pacific Convergence Zone (SPCZ). Our analysis is based on extensive observations of $\mathrm{HO}_{x}$ radicals, their precursors, and related species obtained during the Pacific Exploratory Mission in the tropics (PEM-Tropics B). This mission was designed to provide a detailed picture of tropospheric chemistry over the
South Pacific Basin during the wet season (March-April 1999) [Raper et al., 2001]. Our analysis is based on data from the DC-8 aircraft northeast of Fiji $\left(17^{\circ} \mathrm{S}, 177^{\circ} \mathrm{E}\right)$ as the aircraft traversed an extensive and strong band of SPCZ convection convective outflow at $10-12 \mathrm{~km}$ altitude (section 2).

[4] The SPCZ is a major dynamical feature within the South Pacific. It is characterized by strong upward and downward motions and convective precipitations, and represents a barrier for horizontal atmospheric transport [Gregory et al., 1999]. Air north and south of the SPCZ has distinct chemical signatures, reflective of the impact of long range transport, dry air and subsidence south of the SPCZ and strong ascending motions and precipitations related to convective clouds north of the SPCZ. The SPCZ flight during PEM-Tropics B offers us the opportunity to focus on $\mathrm{HO}_{x}$ sources and chemistry in the tropical upper troposphere along a strong gradient of convective influence.

[5] Our approach is based on a zero-dimensional (0-D) model (section 3) constrained by the ensemble of PEMTropics B aircraft observations. This model allows us to identify the dominant $\mathrm{HO}_{x}$ sources controlling the $\mathrm{HO}_{x}$ concentration in the upper troposphere along the flight track. Budget calculations are then performed and dominant sources are discussed as a function of latitude (section 4).

\section{Experimental Conditions}

[6] Flight 10 was dedicated to the study of SPCZ-related convection. The flight traversed the extensive and strong band of convection, sampling air masses on the edges and the outflow of the convective system (Figure 1). The flight took place during daytime, starting from Fiji on 20 March, 2230 UTC (20 March, 0930 local solar time), ending on 21 March at 0615 UTC (20 March, 1715 local solar time). Figure 2 shows the altitude of the aircraft and the measured values of $\mathrm{NO}_{2}$ photolysis rate as a function of time.

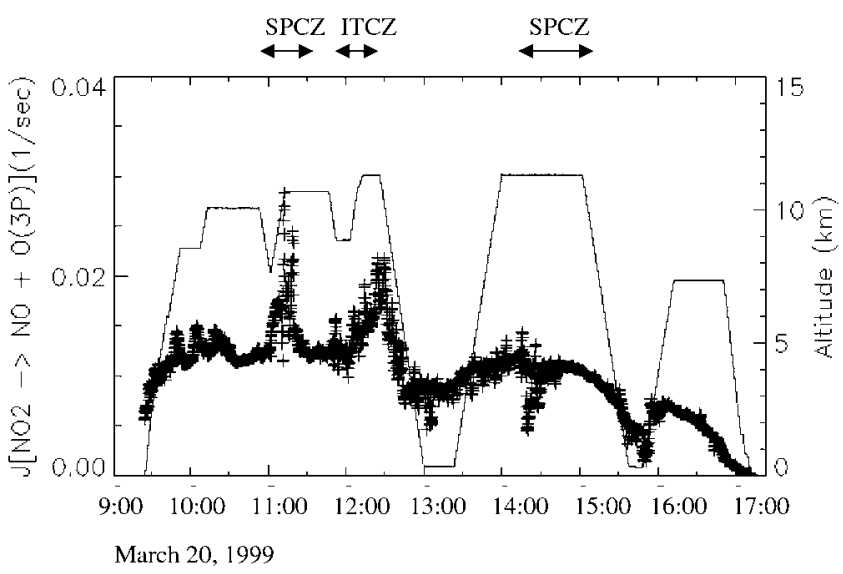

Local solar date and time

Figure 2. Photolysis rate of $\mathrm{NO}_{2}$, in $\mathrm{s}^{-1}$ and altitude of the aircraft, in $\mathrm{km}$, as a function of local solar date and time, during flight 10 . The entire flight took place during daytime, crossing the SPCZ twice during the outbound and returning part of the flight. 


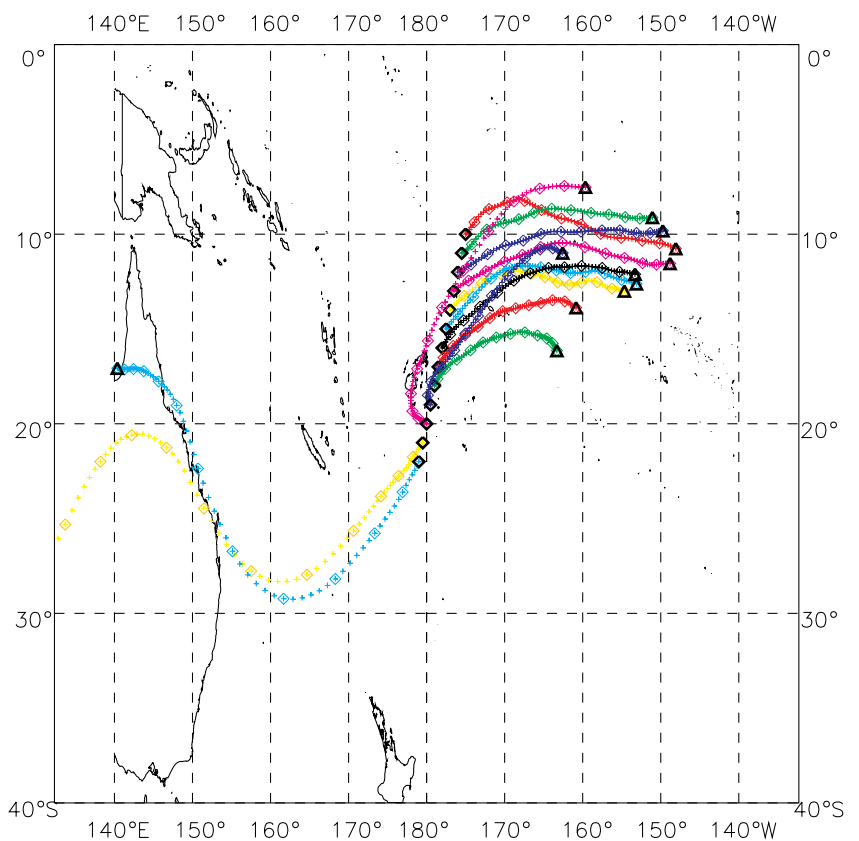

Figure 3. Three-day kinematic backward trajectories from the HYSPLIT4 trajectory model, analyzed meteorological fields are from NCEP/FNL. Trajectories start at $10 \mathrm{~km}$ altitude and are calculated for equally spaced points along flight 10 track. Starting points are marked with diamonds, ending points with triangles.

[7] Chemical variations observed across the SPCZ at 200$300 \mathrm{hPa}$ (Figure 1) showed the transition between subtropical and tropical air masses as well as strong convective influence within the SPCZ itself. In addition to the SPCZ convection area, a near-zonal band of deep convection was present between $5^{\circ}$ and $15^{\circ} \mathrm{S}$ at the northern type of the flight track, commensurate with the southern branch of the ITCZ [Fuelberg et al., 2001]. The satellite image of Figure 1 displays two distinct regions: a region north of the SPCZ, characterized by a strong convective activity and a cloud free region south of the SPCZ characterized by dry air and subsidence. We calculated 3-day kinematic backward trajectories using the Hybrid Single-Particle Lagrangian Integrated Trajectory (HYSPLIT4) 1997 model (Web address: http://www.arl. noaa.gov/ready/hysplit4.html, NOAA Air Resources Laboratory, Silver Spring, MD) starting at $10 \mathrm{~km}$ altitude along the flight track (Figure 3). Most of the trajectories showed a weak northeasterly flow of tropical maritime air, with those South of $20^{\circ} \mathrm{S}$ traversing Australia within the past 2 weeks.

[8] In Figure 1 and Table 1, median concentrations at 8$12 \mathrm{~km}$ altitude observed along the flight track are reported for four distinct regions. In the southern part of the track (south of $20^{\circ} \mathrm{S}$ ), relatively high concentrations of ozone (mean value $32 \mathrm{ppbv}$ ), NO (mean value $29 \mathrm{pptv}$ ) and small enhancements of $\mathrm{CO}$ (up to $58 \mathrm{ppbv}$ ) were measured (Figure 4), suggesting some continental influence. Indeed, back trajectories indicate that air arriving on the southwest side of the SPCZ in the upper troposphere originated from Australia (Figure 3). Pickering et al. [2001] also concluded that air arriving on the southwest side of the SPCZ at $11 \mathrm{~km}$ likely consisted of outflow from deep convection over northern Australia 3 days earlier. Observed PAN and $\mathrm{HNO}_{3}$ concentrations were also relatively high in this region (median values 59 pptv and 109 pptv, respectively). High mixing ratios of acetone and methanol were measured in the southwest-portion of the flight suggesting a continental biogenic origin of the sampled air mass [Jacob et al.,

Table 1. Median Observations in the Upper Troposphere (8 to $12 \mathrm{~km}$ ) for the Four Latitudinal Regions Along the Flight Track in Figure $1^{\mathrm{a}}$

\begin{tabular}{|c|c|c|c|c|}
\hline Observations & $\begin{array}{c}24^{\circ}-20^{\circ} \mathrm{S} \\
\text { South of SPCZ }\end{array}$ & $\begin{array}{c}20^{\circ}-17^{\circ} \mathrm{S} \\
\mathrm{SPCZ} \\
\end{array}$ & $\begin{array}{c}17^{\circ}-13^{\circ} \mathrm{S} \\
\text { North of SPCZ }\end{array}$ & $\begin{array}{c}13^{\circ}-10^{\circ} \mathrm{S} \\
\text { ITCZ }\end{array}$ \\
\hline Pressure, $\mathrm{hPa}$ & $262(215-350)$ & $216(215-348)$ & $238(216-341)$ & $245(216-350)$ \\
\hline Temperature, $\mathrm{K}$ & $233(224-250)$ & $225(223-250)$ & $229(224-250)$ & $232(224-251)$ \\
\hline Ozone column, DU & $254(253-261)$ & $253(250-254)$ & $251(250-253)$ & $258(253-259)$ \\
\hline $\mathrm{H}_{2} \mathrm{O}, \mathrm{ppmv}$ & $86(36-393)$ & $296(65-1268)$ & $165(97-1469)$ & $354(136-2304)$ \\
\hline RH (water), & $22(5-43)$ & $77(9-154)$ & $61(20-93)$ & $86(26-106)$ \\
\hline RH (ice), & $19(4-44)$ & $76(7-163)$ & $58(17-91)$ & $85(23-107)$ \\
\hline $\mathrm{OH}, \mathrm{pptv}$ & $0.24(0.12-0.39)$ & $0.23(0.13-0.34)$ & $0.18(0.09-0.27)$ & $0.24(0.13-0.53)$ \\
\hline $\mathrm{HO}_{2}$, pptv & $6(3-10)$ & $7(3-13)$ & $7(5-9)$ & $9(7-14)$ \\
\hline $\mathrm{H}_{2} \mathrm{O}_{2}, \mathrm{ppbv}$ & $146(97-502)$ & $160(80-352)$ & $174(101-263)$ & $201(114-481)$ \\
\hline $\mathrm{CH}_{3} \mathrm{OOH}, \mathrm{ppbv}$ & $67(34-158)$ & $116(30-304)$ & $100(37-212)$ & $116(45-181)$ \\
\hline $\mathrm{CH}_{2} \mathrm{O}, \mathrm{ppbv}$ & $80(56-306)$ & $110(56-182)$ & $96(52-253)$ & $118(80-201)$ \\
\hline $\mathrm{NO}, \mathrm{pptv}$ & $29(5-59)$ & $10(7-38)$ & $10(6-19)$ & $12(6-78)$ \\
\hline $\mathrm{HNO}_{3}$, pptv & $109(51-145)$ & $37(5-135)$ & $26(9-52)$ & $39(33-42)$ \\
\hline $\mathrm{O}_{3}, \mathrm{ppbv}$ & $32(17-55)$ & $14(10-41)$ & $15(13-21)$ & $15(12-19)$ \\
\hline $\mathrm{CH}_{3} \mathrm{I}, \mathrm{pptv}$ & $0.08(0.02-0.17)$ & $0.21(0.08-0.40)$ & $0.11(0.08-0.19)$ & $0.13(0.07-0.16)$ \\
\hline $\mathrm{CO}, \mathrm{pptv}$ & $48(42-58)$ & $46(41-54)$ & $49(46-51)$ & $49(47-54)$ \\
\hline PAN, pptv & $59(10-117)$ & $10(8-113)$ & $8(7-14)$ & $9(8-12)$ \\
\hline Methanol, pptv & $2706(402-2866)$ & $895(402-1780)$ & $1841(903-2740)$ & $786(395-2589)$ \\
\hline Ethane, pptv & $228(195-278)$ & $229(173-285)$ & $254(234-261)$ & $258(247-263)$ \\
\hline Propane, pptv & $6(4-11)$ & $5(3-7)$ & $6(4-7)$ & $6(4-8)$ \\
\hline $\mathrm{CH}_{4}$, pptv & $1715(1706-1742)$ & $1713(1700-1733)$ & $1714(1708-1718)$ & $1715(1706-1721)$ \\
\hline Acetone, pptv & $509(303-533)$ & $372(304-454)$ & $423(388-544)$ & $351(337-373)$ \\
\hline $\begin{array}{l}\text { Aerosol surface area } \\
\quad \text { (liquid and ice) }, \mu \mathrm{m}^{2} \mathrm{~cm}^{-3}\end{array}$ & $3(1-4)$ & $1135(1-149352)$ & $3(0-39201)$ & $741(0-6479)$ \\
\hline
\end{tabular}

\footnotetext{
${ }^{a}$ The values are medians. The minimum and maximum are listed in parentheses.
} 


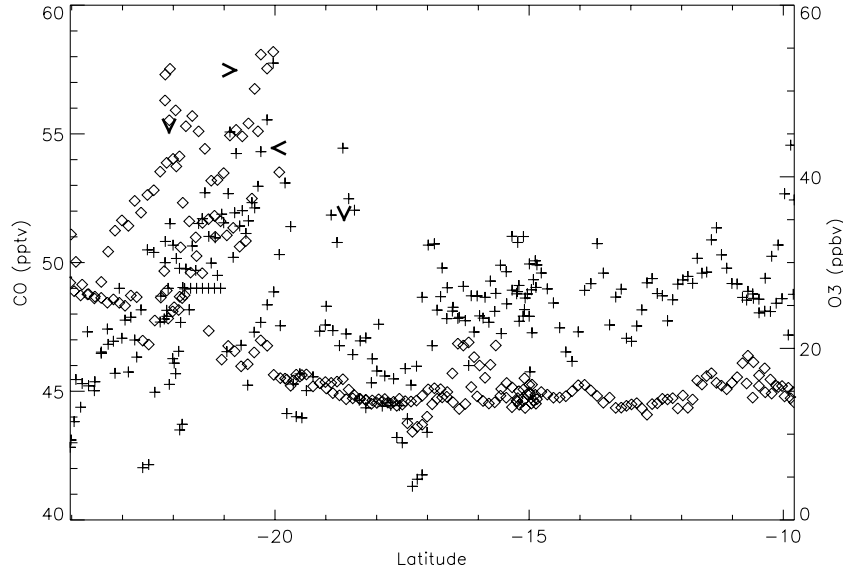

Figure 4. $\mathrm{CO}$ (crosses) and $\mathrm{O}_{3}$ (diamonds) mixing ratios, respectively in pptv and ppbv, as a function of latitude, for both outbound and return parts of flight 10 .

2002]. In contrast, ethane and propane, emitted preferentially by anthropogenic sources, have constant mixing ratios as a function of latitude. For the regions further north, PAN and $\mathrm{HNO}_{3}$ median mixing ratios were lower than 10 and 40 pptv, respectively. The region south of the SPCZ was characterized by strong subsidence associated with the upper tropospheric subtropical jet. Consequently in this region, water vapor concentrations were low (median value 86 ppmv).

[9] The flight segment between $17^{\circ}$ and $20^{\circ} \mathrm{S}$ was characterized by deep convection associated with the SPCZ as evidenced by high concentrations of water vapor, $\mathrm{CH}_{3} \mathrm{I}$ and $\mathrm{CH}_{3} \mathrm{OOH}$ and low concentrations of ozone and NO. Between $13^{\circ} \mathrm{S}$ and $17^{\circ} \mathrm{S}$, the air mass was drier, but NO and ozone concentrations remained low. Finally, the northernmost part of the flight took place in ITCZ convective outflow with chemical composition very similar to that of the SPCZ outflow.

\section{Model Description}

[10] We use a steady state photochemical box model [Crassier et al., 1999] including the Regional Atmospheric Chemistry Model (RACM) mechanism [Stockwell et al., 1997]. This mechanism is suitable for representation of remote to polluted urban conditions. The model is constrained with the observed 1-minute averages of the concentrations along the flight track for species other than $\mathrm{HO}_{x}$. The constrained species are $\mathrm{NO}_{x}\left(\mathrm{NO}+\mathrm{NO}_{2}\right), \mathrm{O}_{3}, \mathrm{H}_{2} \mathrm{O}$, $\mathrm{CO}, \mathrm{CH}_{4}$, acetone, propane, methanol, ethanol, ethane, PAN, $\mathrm{HNO}_{3}, \mathrm{H}_{2} \mathrm{O}_{2}$ and $\mathrm{CH}_{3} \mathrm{OOH}$. When measurements were unavailable, median values shown in Table 1 were used for model calculation. The constrained parameters are held constant throughout each simulation. NO is allowed to vary diurnally and is constrained so that the NO concentration matches the measurement at the time of the day of the observation. Temperature, pressure and aerosol surface area are also determines from the aircraft observations. Photolysis rates are calculated for clear sky conditions with the NCAR Tropospheric Ultraviolet-Visible radiative transfer code [Madronich and Weller, 1990], scaled to the values of $\mathrm{J}\left(\mathrm{NO}_{2}\right)$ observed aboard the aircraft [Shetter et al., 2002] to account for cloud effects using the correction factor $\mathrm{J}\left(\mathrm{NO}_{2}\right)$ observed $/ \mathrm{J}\left(\mathrm{NO}_{2}\right)$ clear sky. For wavelengths smaller than those relevant for $\mathrm{J}\left(\mathrm{NO}_{2}\right)$, this approach can lead to a slight overcorrection of the photolysis rate (for example $\left.\mathrm{J}\left(\mathrm{O}^{1} \mathrm{D}\right)\right)$.

[11] Heterogeneous reactions of $\mathrm{HO}_{2}, \mathrm{NO}_{2}, \mathrm{NO}_{3}$ and $\mathrm{N}_{2} \mathrm{O}_{5}$ in aerosols are included with reaction probabilities of $0.1,0.0001,0.01$, and 0.1 respectively [Jacob, 2000] and assuming aerosols to be aqueous. Aerosol surface areas measured during flight 10 remained around $3 \mu \mathrm{m}^{2} \mathrm{~cm}^{-3}$ except in cirrus clouds associated with convective outflow, where surface areas were considerably higher (see Table 1). In these cirrus clouds, a reaction probability of 0.025 was used for $\mathrm{HO}_{2}$ following Cooper and Abbatt [1996].

[12] The photochemical model is integrated to diurnal steady state as defined by reproducibility of concentrations over a one-day cycle. $\mathrm{CH}_{2} \mathrm{O}$ is a prognostic variable in photochemical steady state in the model; however, the model systematically underestimates the observations by a factor of 2 to 6 . A similar difficulty in simulating $\mathrm{CH}_{2} \mathrm{O}$ has been pointed out for the ensemble of PEM-Tropics B data [Ravetta et al., 2000] and in previous studies [Schultz et al., 1999; Jaeglé et al., 2001]. According to Singh et al. [2000], heterogeneous conversion of methanol to $\mathrm{CH}_{2} \mathrm{O}$ on aerosols might provide an additional source of formaldehyde. During Flight 10, however, no clear correlation was found between methanol and aerosol surface area. Constraining $\mathrm{CH}_{2} \mathrm{O}$ with observed values increases of $\mathrm{HO}_{2}$ mixing ratios by $25 \%$.

[13] Peroxides in the upper troposphere may be produced locally, serving as reservoirs for $\mathrm{HO}_{x}$, or they may be convected from lower altitudes, providing a primary source of $\mathrm{HO}_{x}$ to the upper troposphere [Jaeglé et al., 1997; Prather and Jacob, 1997; Cohan et al., 1999; Mari et al., 2000]. The impact of convective injection can be estimated by comparison of the photochemical steady state concentrations computed from the model with observed values (results of both nonlocal and local contributions). Local contribution was determined from a steady state photochemical calculation with all the normally fixed species except $\mathrm{CH}_{3} \mathrm{OOH}$ and $\mathrm{H}_{2} \mathrm{O}_{2}$. The ratio of measured-tocalculated concentrations in the upper troposphere then provides a good indicator of nonlocal contribution if higher than unity. A second criteria was applied to determine where nonlocal contribution coincide with convective injection. We looked at air masses for which $\mathrm{CH}_{3} \mathrm{I}$ and relative humidity were in the top octile of measurements at 8-12 $\mathrm{km}$ altitude (i.e., $\mathrm{CH}_{3} \mathrm{I}>0.2 \mathrm{pptv}$ and relative humidity $>89 \%$ ) [Cohan et al., 1999]. Thus, in the following, convected peroxides are defined as the nonlocal portion determined from a steady state calculation when correlated with high $\mathrm{CH}_{3} \mathrm{I}$ and relative humidity. Both criteria lead to the conclusion that convection increased $\mathrm{CH}_{3} \mathrm{OOH}$ by factor of 1.9-5.5, essentially in the SPCZ cloud region (Table 2), suggesting that, in the case of $\mathrm{CH}_{3} \mathrm{OOH}$, convective transport could be important. By contrast, observed median $\mathrm{H}_{2} \mathrm{O}_{2}$ mixing ratios were within $30 \%$ of the photochemical steady state computed by the model, revealing that local photochemistry could sustain the observed $\mathrm{H}_{2} \mathrm{O}_{2}$ mixing ratios without invoking transport. This is also consistent with vertical transport of $\mathrm{H}_{2} \mathrm{O}_{2}$ being limited in the con- 
Table 2. Median Values for the Ratio of Measured-to-Calculated $\mathrm{CH}_{3} \mathrm{OOH}$ and $\mathrm{H}_{2} \mathrm{O}_{2}$ Total Production and Amplification Factor in the Upper Troposphere (8 to $12 \mathrm{~km}$ ) for the Four Regions Along the Flight Track in Figure $1^{\mathrm{a}}$

\begin{tabular}{lcccc}
\hline & $24^{\circ}-20^{\circ} \mathrm{S}$ & $20^{\circ}-17^{\circ} \mathrm{S}$ & $17^{\circ}-13^{\circ} \mathrm{S}$ & $13^{\circ}-10^{\circ} \mathrm{S}$ \\
& South of SPCZ & $\mathrm{SPCZ}$ & North of SPCZ & ITCZ \\
\hline $\mathrm{H}_{2} \mathrm{O}_{2}$ (meas/calc) & $0.98(0.63-3.6)$ & $0.78(0.13-1.73)$ & $1.03(0.23-1.38)$ & $0.87(0.4-1.60)$ \\
$\mathrm{CH}_{3} \mathrm{OOH}$ (meas/calc) & $1.03(0.32-1.97)$ & $1.44(0.23-5.55)$ & $1.33(0.37-3.63)$ & $1.23(0.43-3.14)$ \\
$\mathrm{Total} \mathrm{HO}_{x}$ production pptv/d & $1577(589-4121)$ & $1270(563-4271)$ & $1238(537-2619)$ & $2349(1347-6890)$ \\
Amplification factor $^{\mathrm{b}}$ & $1.32(1.09-1.80)$ & $1.14(0.95-1.56)$ & $1.22(1.01-1.29)$ & $1.12(0.86-1.54)$ \\
\hline
\end{tabular}

${ }^{\mathrm{a}}$ The values are medians. The minimum and maximum values are listed in parentheses.

${ }^{\mathrm{b}}$ Amplification factor for methane oxidation $A_{\mathrm{CH}_{4}}$ is defined as the relative increase in the primary source of $\mathrm{HO}_{x}$ due to oxidation of $\mathrm{CH}_{4}$ by $\mathrm{OH}$.

vective updrafts by scavenging by convective precipitations [Crawford et al., 1999; Mari et al., 2000; Pickering et al., 2001].

[14] In the following analysis, we consider the primary sources of $\mathrm{HO}_{x}$ from photolysis of convected $\mathrm{CH}_{3} \mathrm{OOH}$ and $\mathrm{H}_{2} \mathrm{O}_{2}$, photolysis of acetone and photolysis of ozone with subsequent reaction of $\mathrm{O}\left({ }^{1} \mathrm{D}\right)$ with water vapor. In order to quantify the relative importance of these primary sources of $\mathrm{HO}_{x}$, we adapted the method described in previous investigations to our chemical mechanism [Arnold et al., 1997; Folkins and Chatfield, 2000; Jaeglé et al., 2001]. This method is based on the calculation of $\mathrm{HO}_{x}$ yields (i.e., the total number of $\mathrm{HO}_{x}$ molecules generated for each molecule of precursor photolyzed). The primary $\mathrm{HO}_{x}$ production, $P\left(\mathrm{HO}_{x}\right)$ can then be expressed following Jaeglé et al. [2001]:

$$
P\left(\mathrm{HO}_{x}\right)=2 \mathrm{k}\left[\mathrm{O}\left({ }^{1} \mathrm{D}\right)\right]\left[\mathrm{H}_{2} \mathrm{O}\right]+\sum_{i} Y_{i} J_{i}\left[\mathrm{X}_{\mathrm{i}}\right]
$$

where $\mathrm{X}_{i}$ is either $\mathrm{CH}_{3} \mathrm{OOH}, \mathrm{H}_{2} \mathrm{O}_{2}$, or acetone, $J_{i}$ is the associated photolysis rate, and $Y_{i}$ is the corresponding yield.

[15] Oxidation of methane is considered as a secondary source of $\mathrm{HO}_{x}$ because it depends on the initial concentration of available $\mathrm{OH}$ [Wennberg et al., 1998; Jaeglé et al., 2001]. A measure of the amplification of $\mathrm{HO}_{x}$ production by this autocatalytic source is given by the amplification factor calculated following Jaeglé et al. [2001] and defined as the relative increase in the primary source of $\mathrm{HO}_{x}$ due to oxidation of $\mathrm{CH}_{4}$ by $\mathrm{OH}$ :

$$
A_{\mathrm{CH}_{4}}=\frac{P\left(\mathrm{HO}_{x}\right)+y_{\mathrm{CH}_{4}} \mathrm{k}[\mathrm{OH}]\left[\mathrm{CH}_{4}\right]}{P\left(\mathrm{HO}_{x}\right)}
$$

[16] In Figure 5, we examine the trend of $\mathrm{HO}_{x}$ yields from $\mathrm{CH}_{3} \mathrm{OOH}$, acetone and $\mathrm{CH}_{4}$ as a function of $\mathrm{NO}_{x}$ mixing ratios and $P\left(\mathrm{HO}_{x}\right)$ calculated by the box model. The $\mathrm{HO}_{x}$ yields from methane and acetone increase with increasing $\mathrm{NO}_{x}$. The $\mathrm{HO}_{x}$ yield from $\mathrm{CH}_{4}$ increases with $\mathrm{NO}_{x}$ from about 0.25 at $\mathrm{NO}_{x}=10$ pptv to 0.5 at $\mathrm{NO}_{x}=60$ pptv and decreases with increasing $\mathrm{HO}_{x}$ production rate from 0.5 to nearly zero. These variations are consistent with previous studies [Folkins and Chatfield, 2000; Jaeglé et al., 2001]. The $\mathrm{HO}_{x}$ yield from acetone increases with increasing $\mathrm{NO}_{x}$ and decreasing primary production. This variation reflects the greatest impact of acetone on tropospheric chemistry for high $\mathrm{NO}_{x}$ mixing ratios. The $\mathrm{HO}_{x}$ yield from $\mathrm{CH}_{3} \mathrm{OOH}$ decreases with increasing $\mathrm{NO}_{x}$ and increasing primary production from about 1.7 at $\mathrm{NO}_{x}=10$ pptv and $P\left(\mathrm{HO}_{x}\right)=$
$100 \mathrm{pptv} / \mathrm{d}$ down to 1.3 at $\mathrm{NO}_{x}=60 \mathrm{pptv}$ and $P\left(\mathrm{HO}_{x}\right)=1500$ pptv/d similar to the values calculated by Folkins and Chatfield [2000].

\section{Comparison Between Model and Observations}

[17] Figure 6 compares simulated and observed $\mathrm{HO}_{2}$ and $\mathrm{OH}$ mixing ratios for each individual point of the 1-minutes merge data set in the upper troposphere above $8 \mathrm{~km}$. Also

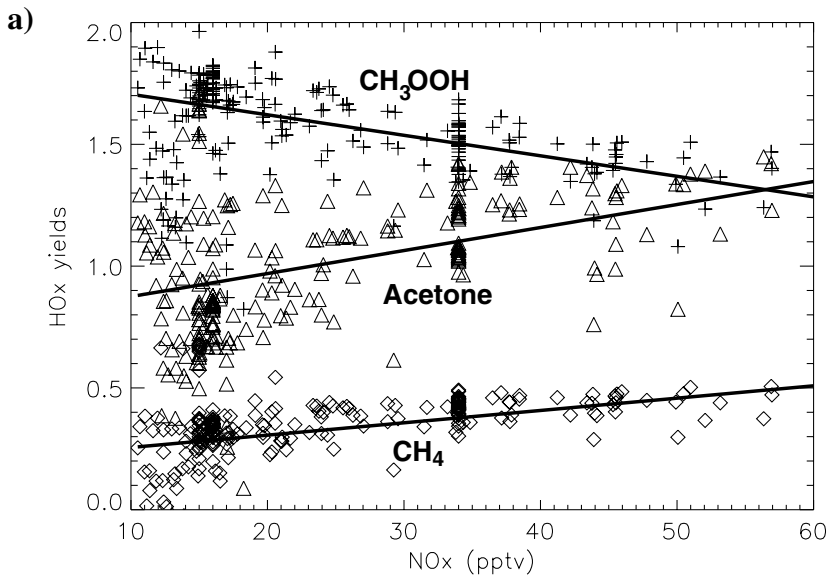

b)

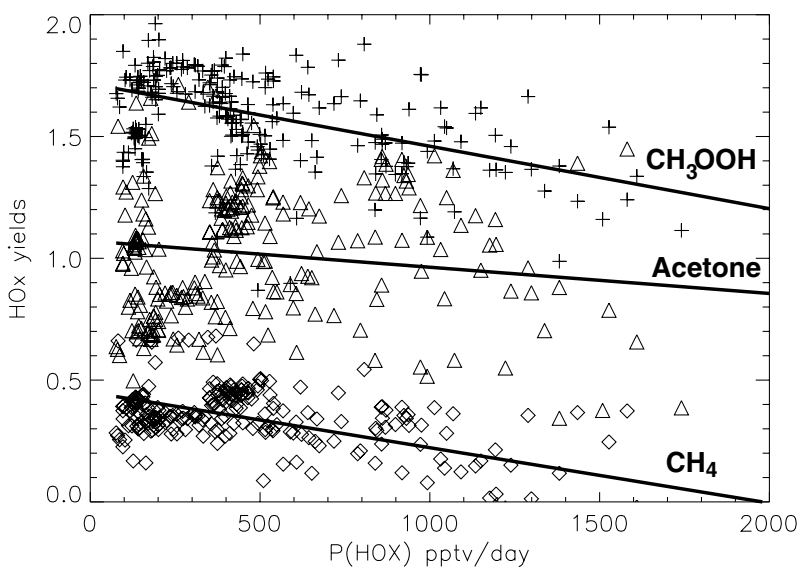

Figure 5. Calculated $\mathrm{HO}_{x}$ yields from methane (diamonds), methylhydroperoxide (crosses) and acetone (triangles) during flight 10 for each simulated point as a function of (a) $\mathrm{NO}_{x}$ mixing ratios and (b) total primary production rates, $P\left(\mathrm{HO}_{x}\right)$. Regression lines (solid) are also plotted for each yield. 
a)

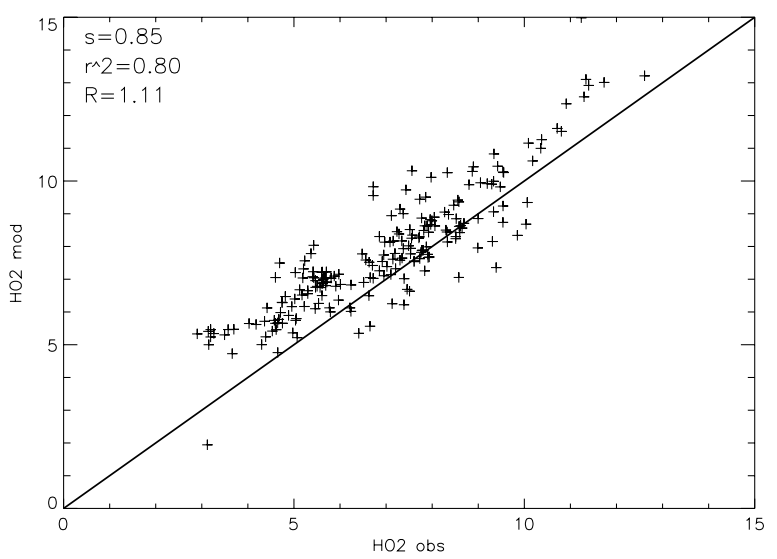

b)

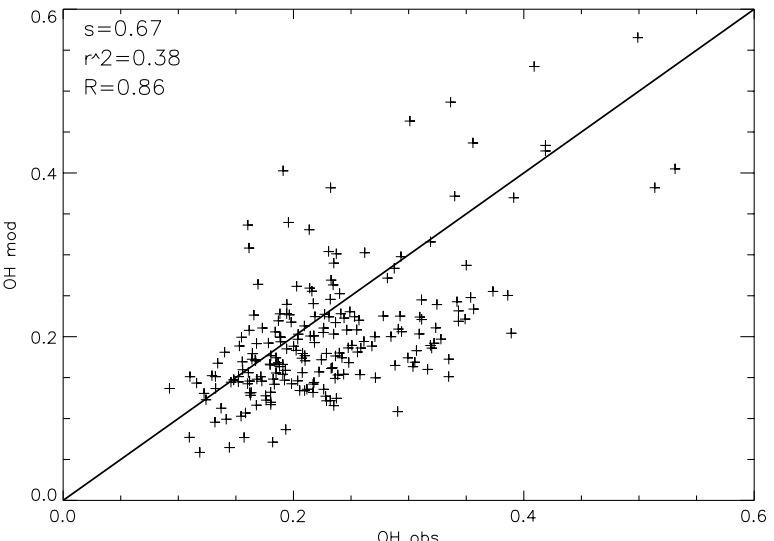

c)

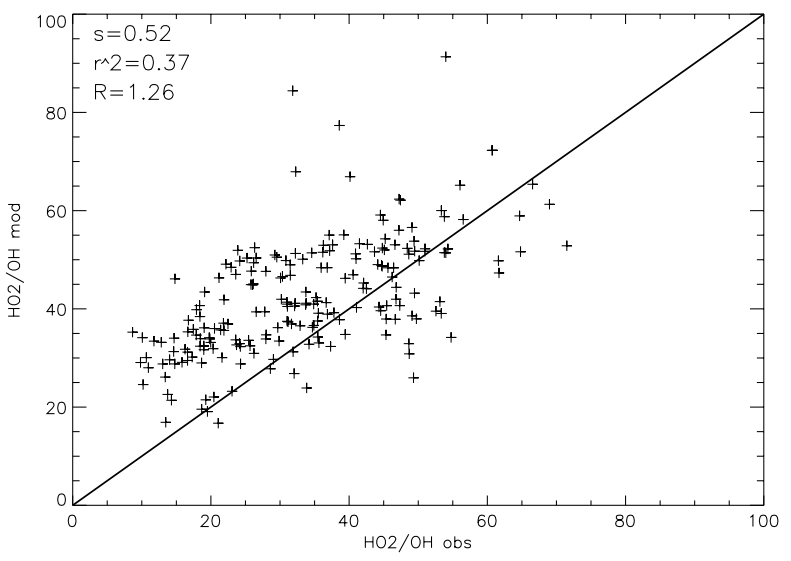

Figure 6. Comparison between observations and model calculations for (a) $\mathrm{HO}_{2}$ mixing ratios, in pptv, (b) $\mathrm{OH}$ mixing ratios, in pptv and (c) $\mathrm{HO}_{2} / \mathrm{OH}$ mixing ratio in the upper troposphere $(8 \mathrm{~km}$ to $12 \mathrm{~km})$. One minutes averages corresponding to PEM-Tropics B Flight 10 are shown by crosses. Also listed are the slope (s) of the linear fit, the least squares correlation coefficient $\left(\mathrm{r}^{2}\right)$ between model and observations, and the median ratio $(\mathrm{R})$ of simulated-toobserved mixing ratios.

shown in this plot are the least squares correlation coefficient $\left(r^{2}\right)$ between model and observations, the slope $(s)$ of the linear fit obtained by the multilinear regression method [Bevington, 1969], and the median ratio $(R)$ of simulated-toobserved mixing ratios. We find that the model captures $80 \%$ of the variance of the observed $\mathrm{HO}_{2}$ concentrations. The median simulated-to-observed ratio is 1.1 and the slope of the linear fit is 0.85 . The simulation of $\mathrm{OH}$ mixing ratio is poorer with $38 \%$ of the variance of observed $\mathrm{OH}$ captured by the model. The median simulated-to-observed ratio is 0.86 and the slope is 0.67 . Figure 7 shows $\mathrm{HO}_{x}$ mixing ratios from the model and the observations as a function of latitude. A maximum is both measured and simulated in the SPCZ region ( $13.5 \mathrm{pptv})$ at $19^{\circ} \mathrm{S}$. In the northern edge of the SPCZ region, simulated $\mathrm{HO}_{x}$ mixing ratios decrease sharply under $1 \mathrm{pptv}$ due to high aerosol surface areas representative of cirrus clouds. There were no observations under these conditions. Two maxima are calculated and observed in the southern branch of the ITCZ with $\mathrm{HO}_{x}$ levels rising up to 13 and $15 \mathrm{pptv}$, respectively. Between the two cloud bands, $\mathrm{HO}_{x}$ mixing ratios are halved and the dry intermediate region is characterized by a minimum of $\mathrm{HO}_{x}$ abundances. The origin of these latitudinal variations is studied in the following section. As seen in Figure 6, the $\mathrm{HO}_{2} / \mathrm{OH}$ ratio varies from 20 to 90 , with the median model to observed ratio for $\mathrm{HO}_{2} / \mathrm{OH}$ of 1.26 . The model represents the observed ratio with a correlation coefficient $r^{2}=0.37$. However, this low correlation coefficient is better than the one obtained for the entire set of data during PEM-Tropics
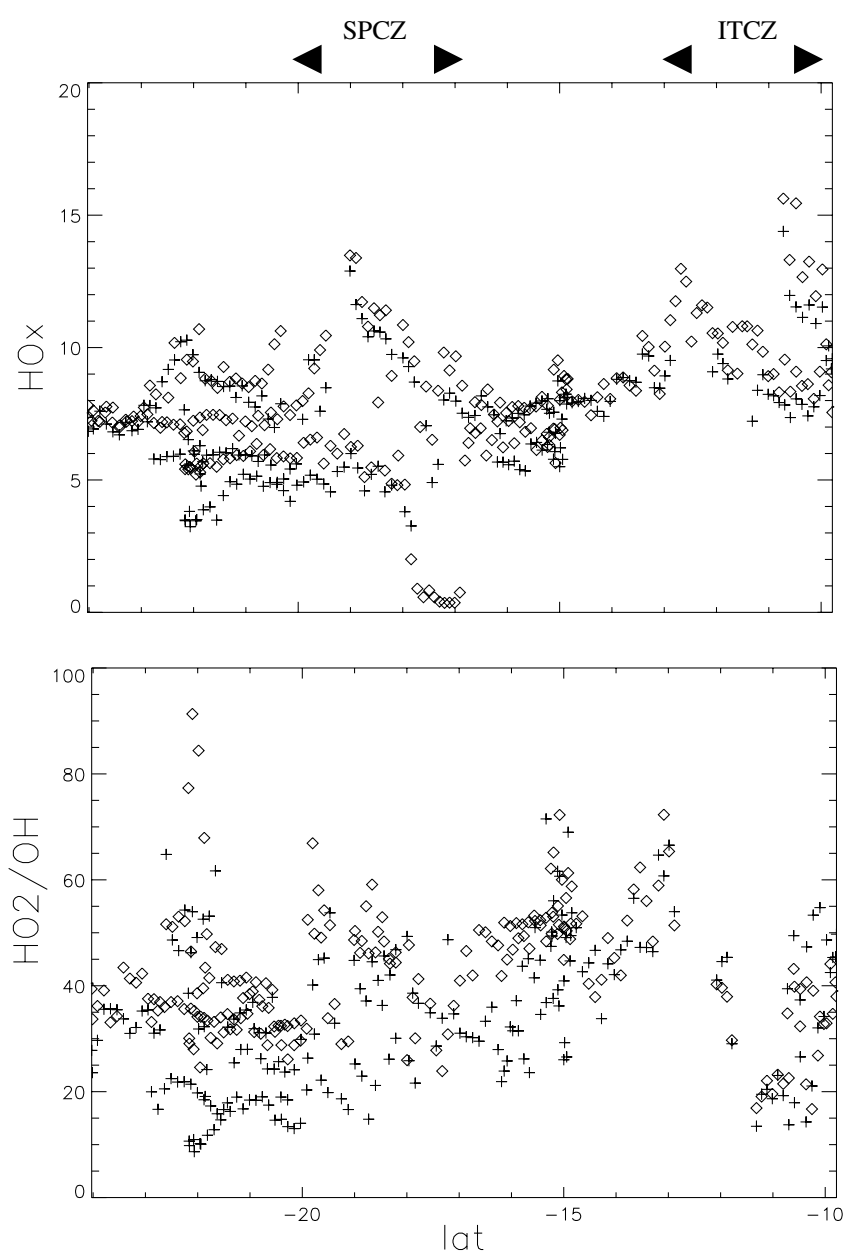

Figure 7. Comparison of simulated (diamonds) and observed (crosses) (a) $\mathrm{HO}_{x}$ mixing ratios, in pptv, and (b) $\mathrm{HO}_{2} / \mathrm{OH}$ ratio, as a function of latitude, for both outbound and return parts of flight 10 . 


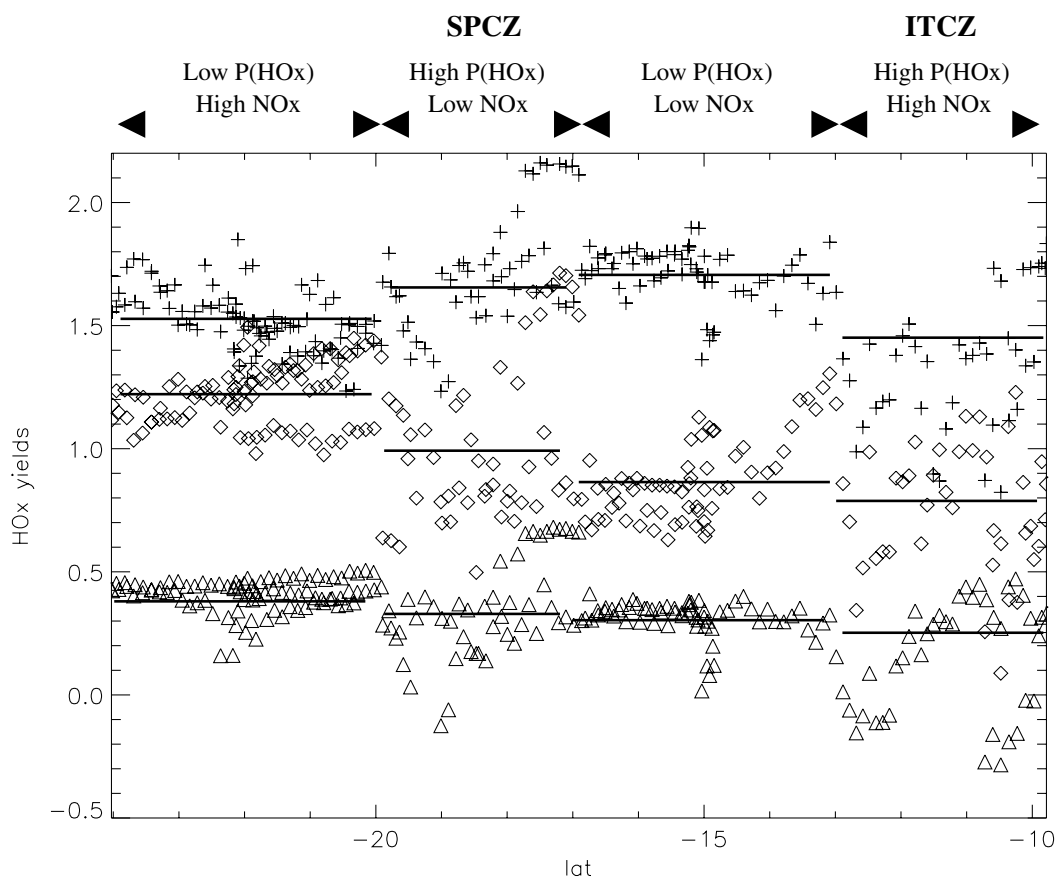

Figure 8. $\mathrm{HO}_{x}$ yields of (triangles) $\mathrm{CH}_{4}, \mathrm{CH}_{3} \mathrm{OOH}$ (crosses) and acetone (diamonds) as a function of latitude. Solid segments represent averaged values of $\mathrm{CH}_{4}, \mathrm{CH}_{3} \mathrm{OOH}$, and acetone yields in the four latitudinal regions in Figure 1. $P\left(\mathrm{HO}_{x}\right)$ stands for total primary production rate.

$\mathrm{B}\left(r^{2}=0.01\right.$ in the 6 - to $12-\mathrm{km}$ altitude range; Ravetta et al., submitted). In Figure 7, the variation of the $\mathrm{HO}_{2} / \mathrm{OH}$ ratio with latitude shows a region of enhanced values south of $20^{\circ} \mathrm{S}$, where NO concentrations were also largest. The model simulates the observed peaks of $\mathrm{HO}_{2} / \mathrm{OH}$ ratio along the flight track, although, it tends to slightly overestimate the ratio.

\section{Primary Sources of $\mathrm{HO}_{\boldsymbol{x}}$}

[18] In order to quantify and better understand the processes involved in the variation of the $\mathrm{HO}_{x}$ levels as a function of latitude, we perform a budget calculation following the methodology described above. Figure 8 shows the variation of $\mathrm{HO}_{x}$ yields as a function of latitude for methylhydroperoxide, acetone, and methane in the four regions described previously. The $\mathrm{HO}_{x}$ yield of acetone is maximum south of $20^{\circ} \mathrm{S}$ as could be expected in a region of relatively high $\mathrm{NO}_{x}$ mixing ratios and low $P\left(\mathrm{HO}_{x}\right)$. The yield is minimum north of $10^{\circ} \mathrm{S}$ where the impact of high $\mathrm{NO}_{x}$ mixing ratios is counteracted by high $P\left(\mathrm{HO}_{x}\right) . \mathrm{HO}_{x}$ yield $\mathrm{CH}_{3} \mathrm{OOH}$ is maximum in the cloud free region between SPCZ and the zonal cloud band, characterized by low $\mathrm{NO}_{x}$ mixing ratio and low $P\left(\mathrm{HO}_{x}\right)$. In contrast, minimum values are calculated above $13^{\circ} \mathrm{S}$ where mean $\mathrm{NO}_{x}$ mixing ratio and $P\left(\mathrm{HO}_{x}\right)$ are higher. The upper troposphere in the tropical region sampled during PEM-Tropics B is characterized by high $\mathrm{HO}_{x}$ production rates (around 2000 pptv/d) and low $\mathrm{NO}_{x}$ concentrations ( $\left.<60 \mathrm{pptv}\right)$. Under these conditions, negative values of yield from $\mathrm{HO}_{x}$ can be predicted as shown in Figure 8. During this flight, we found a maximum amplification of the primary source due to the oxidation of methane $\left(\mathrm{A}_{\mathrm{CH}_{4}}=1.80\right)$ in the southern- most region for points combining maximum observed $\mathrm{NO}$ levels $\left(40<\mathrm{NO}<60\right.$ pptv) and low $P\left(\mathrm{HO}_{x}\right)(<200 \mathrm{pptv} / \mathrm{d})$. Only $6 \%$ of the simulated points reveal a small quenching $\left(\mathrm{A}_{\mathrm{CH}_{4}}\right.$. These points correspond to observed NO levels lower than 20 pptv and $P\left(\mathrm{HO}_{x}\right)$ higher than $1000 \mathrm{pptv} / \mathrm{d}$. Thus, the amplification is largest when is low $P\left(\mathrm{HO}_{x}\right)$ and $\mathrm{NO}_{x}$ mixing ratio is high. This result is concordant with previous findings showing that the dependence of $\mathrm{A}_{\mathrm{CH}_{4}}$ on $P\left(\mathrm{HO}_{x}\right)$ acts as a weak buffer for $\mathrm{HO}_{x}$ concentrations [Crawford et al., 1999; Jaeglé et al., 2001].

[19] Dominant primary production terms are plotted in Figure 9 in the 10- to 12-km altitude range where convective injection of $\mathrm{CH}_{3} \mathrm{OOH}$ was identified. A large fraction of the total $\mathrm{HO}_{x}$ production is attributed to water vapor, photolysis of $\mathrm{CH}_{3} \mathrm{OOH}$ pumped by convection from the marine boundary layer and acetone. North of $20^{\circ} \mathrm{S}, \mathrm{HO}_{x}$ production is driven principally by the $\mathrm{O}^{1} \mathrm{D}+\mathrm{H}_{2} \mathrm{O}$ reaction (Table 3 ); this contribution is strongest in the cloudy regions corresponding to the SPCZ and ITCZ cloud bands (Figure 1) where it accounts for $90 \%$ of the total primary production of $\mathrm{HO}_{x}$. We found that $75 \%$ of the simulated $\mathrm{HO}_{x}$ variance is produced by water vapor. In the drier regions south of $20^{\circ} \mathrm{S}$, production from water vapor and acetone are comparable. Production from acetone contributes to $18-81 \%$ of the $\mathrm{HO}_{x}$ primary production in the 8 - to $10-\mathrm{km}$ altitude range (mean contribution $33 \%$ ) and to $36-77 \%$ in the $10-$ to $12-\mathrm{km}$ altitude range (mean contribution $49 \%$ ). We found that production from acetone becomes significant and can be dominant over production from water vapor for water vapor mixing ratios lower than 200 ppmv. Impact of convected $\mathrm{CH}_{3} \mathrm{OOH}$ on the $\mathrm{HO}_{x}$ production is limited to the SPCZ cloud band. The effect of convected $\mathrm{CH}_{3} \mathrm{OOH}$ is sensitive at $10-12 \mathrm{~km}$. In Table 3 , the primary production rate from 


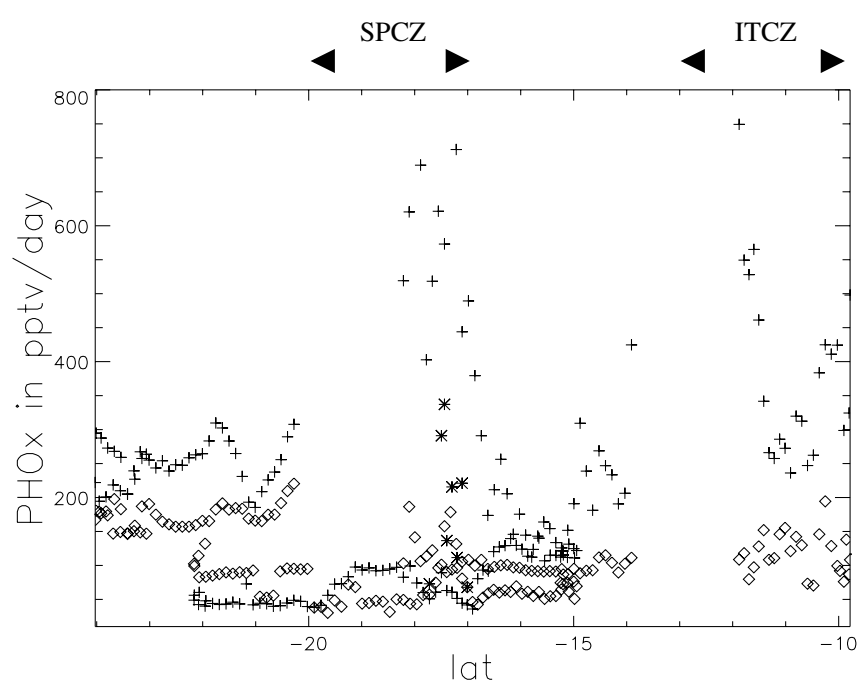

Figure 9. $\mathrm{HO}_{x}$ production rates, in $\mathrm{pptv} / \mathrm{d}$, from water vapor (plusses), convected $\mathrm{CH}_{3} \mathrm{OOH}$ (starts) and acetone (diamonds) as a function of latitude in the 10- to $12-\mathrm{km}$ altitude range, for the four latitudinal regions in Figure 1.

$\mathrm{CH}_{3} \mathrm{OOH}$ accounts for $22 \%$ to $64 \%$ of the total primary source in this altitude range. Clearly, this impact is spatially restricted to the outflow of the cloud.

\section{Conclusion}

[20] A 0-D model is applied to study the photochemistry of $\mathrm{HO}_{x}\left(\mathrm{HO}_{2}+\mathrm{OH}\right)$ in the tropical upper troposphere, during the PEM-Tropics $\mathrm{B}$ experiment. In particular, airborne observations across the SPCZ-related convection gave the opportunity to quantify the relative contribution of the sources of $\mathrm{HO}_{x}$ in a remote nonpolluted tropical region, characterized by $\mathrm{NO}_{x}$-limited conditions and influenced by marine deep convective clouds. The predominant primary sources of $\mathrm{HO}_{x}$ are identified as reaction $\mathrm{O}\left({ }^{1} \mathrm{D}\right)+$ $\mathrm{H}_{2} \mathrm{O}$, photolysis of convected $\mathrm{CH}_{3} \mathrm{OOH}$ and photolysis of acetone. $\mathrm{HO}_{x}$ chemistry shows a latitudinal dependence, reflecting the different origins of the air masses traversed by the aircraft. The southernmost region $\left(<20^{\circ} \mathrm{S}\right)$ is characterized by a strong subsidence associated with the upper tropospheric subtropical jet and advection of air from Australia. Because of the subsidence, water vapor mixing ratios are low and advection of continental air masses induces relatively high $\mathrm{NO}_{x}$ and ozone mixing ratios. In this region, $\mathrm{HO}_{x}$ primary production from acetone and water vapor are comparable, in particular in the $10-$ to $12-\mathrm{km}$ altitude range where production from acetone can account for $36 \%$ to $77 \%$ of the total primary production rate. Amplification of the primary source due to the oxidation of methane shows maximum values $(1.1-1.8)$ in the southernmost dry region. The SPCZ region is characterized by elevated water vapor mixing ratios and convective injection of low soluble species like $\mathrm{CH}_{3} \mathrm{I}$ and $\mathrm{CH}_{3} \mathrm{OOH}$ in the cloud outflow. Total primary production rates are higher than in the southernmost dry region and controlled mainly by water vapor abundances. When enhancement of $\mathrm{CH}_{3} \mathrm{OOH}$ by convective transport is predicted, production from convected $\mathrm{CH}_{3} \mathrm{OOH}$ becomes important and contributes for $22 \%$ to $64 \%$ of the primary production rate. The northern cloud band, corresponding to the southern branch of the ITCZ, is characterized by higher $\mathrm{NO}_{x}$ mixing ratios and $\mathrm{HO}_{x}$ production rates compared to the SPCZ cloud band. No impact of acetone or convected $\mathrm{CH}_{3} \mathrm{OOH}$ is predicted and the reaction $\mathrm{O}\left({ }^{1} \mathrm{D}\right)+\mathrm{H}_{2} \mathrm{O}$ is largely prevailing. This region is also characterized by some occurrences of low $\mathrm{NO}_{x}$ mixing ratios and elevated primary production rates leading to a diminution of $\mathrm{HO}_{x}$ primary sources by oxidation of methane. Between, the two cloud bands the aircraft passed through a dry region characterized by relatively low $\mathrm{NO}_{x}$ mixing ratios, low primary production rates, and minimum $\mathrm{HO}_{x}$ mixing ratios. In this region, production from acetone is important, although rarely dominant, and methane oxidation amplifies the primary source production by $1.0-1.3$. The general good agreement in the clean tropical Pacific upper troposphere should not hide the remaining uncertainties regarding $\mathrm{HO}_{x}$ in the upper troposphere. Problems remain for very high $\mathrm{NO}_{x}$ at which systematic differences between observed and simulated $\mathrm{HO}_{x}$ have been found, reflecting gaps in our understanding of the coupling between $\mathrm{HO}_{x}$ and $\mathrm{NO}_{x}$ [Brune et al., 1999;

Table 3. Mean Relative Contribution of Primary Sources in the Upper Troposphere in the $8-10 \mathrm{~km}$ and 10-12 km Altitude Ranges and for the Four Latitudinal Regions Along the Flight Track in Figure 1

\begin{tabular}{lcccc}
\hline & $24^{\circ}-20^{\circ} \mathrm{S}$ & $20^{\circ}-17^{\circ} \mathrm{S}$ & $17^{\circ}-13^{\circ} \mathrm{S}$ & $13-10^{\circ} \mathrm{S}$ \\
\hline & & $10-12 \mathrm{~km}$ Altitude & \\
$P\left(\mathrm{HO}_{x}\right),{ }^{\mathrm{a}} \mathrm{pptv} / \mathrm{d}$ & $322(95-528)^{\mathrm{b}}$ & $374(76-1727)$ & $254(82-598)$ & $549(320-1223)$ \\
$P\left(\mathrm{HO}_{x}\right)\left(\mathrm{O}^{1} \mathrm{D}+\mathrm{H}_{2} \mathrm{O}\right), \%$ & $51(23-64)$ & $59(13-91)$ & $66(44-82)$ & $77(64-92)$ \\
$P\left(\mathrm{HO}_{x}\right)\left(\mathrm{CH}_{3} \mathrm{OOH}\right), \%$ & $0(0-0)^{\mathrm{c}}$ & $11(0-64)$ & $0(0-0)$ & $0(0-0)$ \\
$P\left(\mathrm{HO}_{x}\right)($ acetone $), \%$ & $49(36-77)$ & $30(9-55)$ & $34(18-56)$ & $23(8-36)$ \\
& & & \\
& & & \\
$P\left(\mathrm{HO}_{x}\right), \mathrm{pptv} / \mathrm{d}$ & $715(96-1581)$ & $1141(375-2442)$ & $681(171-1193)$ & $1482(510-3832)$ \\
$P\left(\mathrm{HO}_{x}\right)\left(\mathrm{O}^{1} \mathrm{D}+\mathrm{H}_{2} \mathrm{O}\right), \%$ & $67(19-82)$ & $84(59-95)$ & $79(54-91)$ & $93(79-99)$ \\
$P\left(\mathrm{HO}_{x}\right)\left(\mathrm{CH} \mathrm{H}_{3} \mathrm{OOH}\right), \%$ & $0(0-0)$ & $0(0-0)$ & $0(0-0)$ & $0(0-0)$ \\
$P\left(\mathrm{HO}_{x}\right)($ acetone $), \%$ & $33(18-81)$ & $16(5-41)$ & $21(9-46)$ & $7(1-21)$ \\
\hline
\end{tabular}

a Primary sources of $\mathrm{HO}_{x}, P\left(\mathrm{HO}_{x}\right)$ are photolysis of convected $\mathrm{CH}_{3} \mathrm{OOH}$ and $\mathrm{H}_{2} \mathrm{O}_{2}$, photolysis of acetone, and photolysis of ozone with subsequent reaction of $\mathrm{O}\left({ }^{1} \mathrm{D}\right)$ with water vapor. During flight 10 , no convective injection of $\mathrm{H}_{2} \mathrm{O}_{2}$ was identified by the model.

${ }^{\mathrm{b}}$ The values are means. The minimum and maximum are listed in parentheses.

${ }^{\mathrm{c}}$ Zero values mean no contribution from photolysis of convected $\mathrm{CH}_{3} \mathrm{OOH}$ to the total primary source of $\mathrm{HO}_{x}$. 
Faloona et al., 2000]. Chemistry of $\mathrm{HO}_{x}$ at night and sunlight/sunset is still poorly understood [Wennberg et al., 1999; Jaeglé et al., 1999] and the fate of inside cirrus clouds certainly needs further study.

\section{References}

Arnold, F., V. Burger, B. Droste-Franke, F. Grimm, A. Krieger, J. Schneider, and T. Stilp, Acetone in the upper troposphere and lower stratosphere: Impact on trace gases and aerosols, Geophys. Res. Lett., 24, 3017-3020, 1997.

Bevington, P., Data Reduction and Error Analysis for the Physical Sciences, McGraw-Hill, New York, 1969.

Brune, W. $\mathrm{H}$., et al., $\mathrm{OH}$ and $\mathrm{HO}_{2}$ chemistry in the north Atlantic free troposphere, Geophys. Res. Lett., 25, 3077-3080, 1999.

Cohan, D. S., M. G. Schultz, D. J. Jacob, B. G. Heikes, and D. R. Blake, Convective injection and photochemical decay of peroxides in the tropical upper troposphere: Methyl iodide as a tracer of marine convection, J. Geophys. Res., 104, 5717-5724, 1999.

Cooper, P. L., and J. P. D. Abbatt, Heterogeneous interactions of $\mathrm{OH}$ and $\mathrm{HO}_{2}$ radicals with surfaces characteristic of atmospheric particulate matter, J. Phys. Chem., 100, 2249-2254, 1996.

Crassier, V., K. Suhre, P. Tulet, and R. Rosset, Development of a reduced chemical scheme for use in mesoscale meteorological models, Atmos. Environ., 34, 2633-2644, 1999.

Crawford, J., et al., Assessment of upper tropospheric $\mathrm{HO}_{x}$ sources over the tropical Pacific based on NASA GTE/PEM data: Net effect on $\mathrm{HO}_{x}$ and other photochemical parameters, J. Geophys. Res., 104, 16,255-16,273, 1999.

Faloona, et al., Observations of $\mathrm{HO}_{x}$ and its relationship with $\mathrm{NOx}$ in the upper troposphere during SONEX, J. Geophys. Res., 105, 3771-3783, 2000.

Folkins, I., R. Chatfield, H. Singh, Y. Chen, and B. Heikes, Ozone production efficiencies of acetone and peroxides in the upper troposphere, Geophys. Res. Lett., 25, 1305-1308, 1998.

Folkins, I., and R. Chatfield, Impact of acetone on ozone production and $\mathrm{OH}$ in the upper troposphere at high $\mathrm{NO}_{x}$, Geophys. Res. Lett., 105 , $11,585-11,599,2000$.

Gregory, G. L., et al., Chemical characteristics of Pacific tropospheric air in the region of the ITCZ and SPCZ, J. Geophys. Res., 104, 5697-5716, 1999.

Jacob, D. J., Heterogeneous chemistry and tropospheric ozone, Atmos. Environ., 34, 2131-2159, 2000.

Jacob, D. J., B. D. Field, E. Jin, I. Bey, Q. Li, J. A. Logan, and R. M. Yantosca, Atmospheric budget of acetone, J. Geophys. Res., 107(D9), 4100, doi:10.1029/2001JD000694, 2002.

Jaeglé, L., et al., Observed $\mathrm{OH}$ and $\mathrm{HO}_{2}$ in the upper troposphere suggest a major source from convective injection of peroxides, Geophys. Res. Lett. 24, 3181-3184, 1997.

Jaeglé, L., et al., Ozone production in the upper troposphere and the influence of aircraft during SONEX: Approach of $\mathrm{NO}_{x}$-saturated conditions, Geophys. Res. Lett., 26, 3081-3084, 1999

Jaeglé, L., D. J. Jacob, W. H. Brune, and P. O. Wennberg, Chemistry of $\mathrm{HO}_{x}$ radicals in the upper troposphere, Atmos. Environ., 35, 469-489, 2001.

Lefer, B. L., S. R. Hall, L. Cinquini, R. E. Shetter, J. D. Barrick, and J. H. Crawford, Comparison of airborne $\mathrm{NO}_{2}$ photolysis frequency measurements during PEM-Tropics B, J. Geophys. Res., 106, 32,645-32,656, 2001.

Madronich, S., and G. Weller, Numerical integration errors in calculated tropospheric photodissociation rate coefficients, J. Atmos. Sci., 10, 289300, 1990.

Mari, C., D. J. Jacob, and P. Bechtold, Transport and scavenging of soluble gases in a deep convective cloud, J. Geophys. Res., 105(D17), 22,255$22,267,2000$
McKeen, S. A., T. Gierczak, J. B. Burholder, P. O. Wennberg, T. F. Hanisco, E. R. Keim, R.-S. Gao, S. C. Liu, A. R. Ravishankara, and D. W. Fahey, The photochemistry of acetone in the upper troposphere: A source of odd-hydrogen radicals, Geophys. Res. Lett., 24, $3177-$ 3180, 1997

Müller, J.-F., and G. Brasseur, Sources of upper tropospheric $\mathrm{HO}_{x}$ : A threedimensional study, J. Geophys. Res., 104, 1705-1715, 1999.

Pickering, K. E., et al., Trace gas transport and scavenging in PEM Tropics-B SPCZ convection, J. Geophys. Res., 106(D23), 32,591$32,607,2001$

Prather, M. J., and D. J. Jacob, A persistent imbalance in $\mathrm{HO}_{x}$ and $\mathrm{NOx}$ photochemistry of the upper troposphere driven by deep tropical convection, Geophys. Res. Lett., 24, 3189-3192, 1997.

Raper, J. L., M. M. Kleb, D. J. Jacob, D. D. Davis, R. E. Newell, H. E. Fuelberg, R. J. Bendura, J. M. Hoell, and R. J. McNeal, Pacific Exploratory Mission in the Tropical Pacific: PEM-Tropics B, MarchApril 1999, J. Geophys. Res., 106(D23), 32,401-32,425, 2001.

Ravetta, F., et al., Experimental evidence for the importance of convected methylhydroperoxide as a source of hydrogen oxide $\left(\mathrm{HO}_{x}\right)$ radicals in the tropical upper troposphere, J. Geophys. Res., 106, 32,709-32,716, 2001.

Schultz, M. G., et al., On the origin of tropospheric ozone and $\mathrm{NO}_{x}$ over the tropical South Pacific, J. Geophys. Res., 104, 5829-5843, 1999.

Singh, H. B., M. Kanakidou, P. Crutzen, and D. Jacob, High concentrations and photochemistry of carbonyls and alcohols in the global troposphere, Nature, 378, 50-54, 1995.

Singh, et al., Distribution and fate of selected oxygenated organic species in the troposphere and lower stratosphere over the Atlantic, J. Geophys. Res., 105, 3795-3806, 2000.

Stockwell, W. R., F. Kirchner, M. Kuhn, and S. Seefeld, A new mechanism for regional atmospheric chemistry modeling, J. Geophys. Res., 22, 25,847-25,879, 1997.

Wennberg, P. O., et al., Hydrogen radicals, nitrogen radicals and the production of $\mathrm{O}_{3}$ in the upper troposphere, Science, 279, 49-53, 1998. Wennberg, P. O., et al., Twilight observations suggest unknown sources of $\mathrm{HO}_{x}$, Geophys. Res. Lett., 26, 1373-1376, 1999.

B. Anderson, G. L. Gregory, G. W. Sachse, and S. Vay, NASA Langley Research Center, Hampton, VA 23681, USA.

D. Blake, Department of Chemistry, University of California, Irvine, CA 92717, USA.

W. H. Brune, Department of Meteorology, The Pennsylvania State University, University Park, PA 16802-5013, USA

I. Faloona, Atmospheric Chemistry Division, National Center for Atmospheric Research, Boulder, CO 80305, USA.

B. Heikes, Center for Atmospheric Chemistry Studies, University of Rhode Island, Narragansett, RI 02882, USA.

D. J. Jacob, Division of Engineering and Applied Science, Harvard University, Cambridge, MA 02138, USA.

C. Mari and C. Saüt, Laboratoire d'Aérologie, UMR 5560 CNRS/ Université Paul Sabatier, Toulouse, F-31400, France. (marc@aero.obs-mip. fr)

M. Avery, Department of Physics, Hampton University, Hampton, VA 29668, USA.

S. T. Sandholm, Earth and Atmospheric Sciences Baker Building, Georgia Institute of Technology, Atlanta, GA 30332, USA.

H. B. Singh, NASA Ames Research Center, Moffett Field, CA 94035, USA.

F. Ravetta, Service d'Aéronomie du CNRS, Université Paris 6, Boite 102, 4 Place Jussieu, 75252,Paris Cedex 05, France.

R. W. Talbot, CSRC/EOS, University of New Hampshire, Durham, NH 30824, USA.

D. Tan, Georgia Institute of Technology, Atlanta, GA 30332-0340, USA. 